\title{
Cross-cultural adaptation of the Zurich Claudication Questionnaire. Validation study of the Spanish version
}

\author{
Adaptación transcultural de Cuestionario de Claudicación \\ Zurich. Estudio de validación de la versión española
}

\author{
A.M. Hidalgo Ovejero ${ }^{1}$, M. Menéndez García ${ }^{1}$, B. Bermejo Fraile ${ }^{2}$, S. García Mata ${ }^{3}$, \\ T. Forcén Alonso ${ }^{4}$, P. Mateo Sebastián ${ }^{1}$
}

\begin{abstract}
Background. In the last few years, instruments that measure outcomes and quality of life as perceived by the patient have become tools of great clinical value. The Zurich Claudication Questionnaire is one of the main instruments for the assessment of patients suffering from lumbar spinal stenosis. Nonetheless, no valid version has been published for use in the Spanish population.
\end{abstract}

Methods. The Zurich Claudication Questionnaire was translated and cross-culturally adapted to Spanish and the psychometric characteristics of the new version were then studied. Seventy-six patients were selected who were to undergo epidural steroid injection or were seen in the Hospital Complex of Navarre Spinal Unit.

Results. The Spanish version of the Zurich Claudication Questionnaire shows high Cronbach alpha internal consistency values, high reproducibility, a good correlation with the most important low back condition questionnaires used worldwide and good sensitivity for detecting clinical change in patients who undergo epidural steroid injection.

Conclusion. This study resulted in a version of the $\mathrm{Zu}-$ rich Claudication Questionnaire or Swiss Spinal Stenosis Questionnaire translated and cross-culturally adapted to Spanish, with highly reliable, valid and sensitive psychometric characteristics. These proven properties make the Zurich Claudication Questionnaire available for the Spanish population, to evaluate outcomes and health status as perceived by patients with spinal stenosis and claudication syndrome.

Keywords. Spinal stenosis. Zurich claudication questionnaire. Cross-cultural adaptation. Internal consistency.

\section{RESUMEN}

Introducción. En los últimos años, los instrumentos de medida de resultados y calidad de vida percibida por el paciente, se han convertido en herramientas de gran utilidad clínica. El Cuestionario de Claudicación de Zurich es uno de los principales instrumentos para el estudio de los pacientes afectos de estenosis del canal lumbar. Actualmente, no se ha publicado una versión validada para su uso en la población española.

Métodos. El Cuestionario de Claudicación de Zurich ha sido traducido y adaptado transculturalmente al español, y se han estudiado las características psicométricas de la nueva versión. Se seleccionaron 76 pacientes a los que se les iba a realizar una infiltración epidural de esteroides o que eran vistos en consultas de la Unidad de Raquis Quirúrgico del Complejo Hospitalario de Navarra.

Resultados. La versión española del Cuestionario de Claudicación de Zurich muestra altos valores de consistencia interna alfa de Cronbach, alta reproducibilidad, una buena correlación con los cuestionarios de patología lumbar más importantes a nivel mundial, y una buena sensibilidad para detectar cambios clínicos en pacientes a los que se les realiza una infiltración epidural de corticoides.

Conclusión. Se ha obtenido una versión del Cuestionario de Claudicación de Zurich traducida y adaptada transculturalmente al español, con altos valores en las características psicométricas de fiabilidad, validez y sensibilidad. Esto permite, en la población española, evaluar los resultados y el estado de salud percibido por los pacientes con estenosis de canal y síndrome de claudicación.

Palabras clave. Estenosis de canal. Cuestionario de Claudicación de Zurich. Adaptación transcultural. Consistencia interna.
1. Orthopedics Department. Spine Division. Hospital Complex of Navarre.

2. Preventive Medicine and Clinical Management. Hospital Complex of Navarre

3. Orthopedics Pediatrics Division. Orthopedics Department. Hospital Complex of Navarre.

4. Primary Care Physician. Prof of Medicine Area. Public University of Navarre.

\section{Corresponding author:}

Ángel Manuel Hidalgo Ovejero

E-mail: angel@drhidalgo.es

Recepción: 28 de mayo de 2014

Aceptación provisional: 1 de agosto de 2014

Aceptación definitiva: 9 de febrero de 2015 


\section{INTRODUCTION}

Spinal conditions, and specifically conditions affecting the lumbar spine, represent approximately $10-20 \%$ of all primary care visits and are the first cause of absenteeism from work for more than 2 weeks in many countries ${ }^{1,2}$.

The financial burden of these conditions in terms of both direct and indirect costs is extremely high ${ }^{3,4}$ and, although the intangible costs are harder to quantify, it is evident that low back conditions also represent a high psychosocial burden, reducing quality of life due to occupational and familial stress and suffering largely due to the disability caused by the pain ${ }^{5}$.

As a result of the severe impact of this type of condition on the individual, families and society, there is a great deal of interest in instruments for measuring outcomes and quality of life as perceived by patients ${ }^{6}$.

The Oswestry Disability Index (ODI) has become one of the most important specific rating scales and measuring instruments for health status in spinal disease ${ }^{7}$ and, together with the Roland-Morris Questionnaire, is the most recommended survey worldwide ${ }^{8,9}$. However, these instruments do not specifically measure health status as perceived by patients with lumbar spinal stenosis ${ }^{10,11}$.

In lumbar spinal stenosis, the clinical results of treatment are influenced by many non-morphological factors ${ }^{12}$, such as the psychosocial and occupational aspects, which are often of more predictive value than pathophysiological and surgical factors ${ }^{13}$.

The Zurich Claudication Questionnaire (ZCQ), also known as the Swiss Spinal Stenosis Questionnaire (SSSQ), is an instrument that specifically measures outcomes and health status related to lumbar spinal stenosis as perceived by the patient. It was designed to evaluate pain, function and satisfaction in patients undergoing lumbar spine decompression surgery.

Its properties were tested by a prospective, multicentre study in 193 patients who completed the questionnaire before surgery and 6 months later, which is when they expected the maximum benefit from the intervention, in order to better assess sensitivity to change. A random sample of 23 patients received the test by post 2 weeks later in order to assess "test-retest" reproducibility.

It comprises three subscales: the first subscale measures symptom severity (SSS). It comprises 7 items that measure pain severity, pain frequency, back pain, leg pain, numbness or tingling, weakness and balance. These items were chosen emphasising validity of content, as they all represent the main components of disability in lumbar spinal stenosis, including balance, although this is the aspect that least improves with treatment ${ }^{14}$.

The first 3 items represent the overall pain domain (PD) and the last 4 the domain of neuro-ischaemic symptoms (NID). Except for item 7 (balance), which only has 3 responses valued at 1-3-5 (no problems-sometimes-often), the rest have 5 possible values, from less to more severe (none-mild-moderate-severe-very severe).

The second subscale measures physical function (PFS). It assesses distance walked and the ability to walk for pleasure, for shopping and in the home and around the different rooms. It comprises a total of 6 items, with four categories valued from 1 to 4 (comfortably-sometimes with pain-always with pain-no).

The third subscale measures the patient's satisfaction (PSATS) with the surgery. The 5 items, classified in 4 categories (from very satisfied to very dissatisfied), evaluate the overall outcome, pain relief, ability to walk, ability to work, do housework or gardening, strength and balance. The score is calculated by the unweighted mean value of each of the subscales.

The authors showed the test's internal consistency, reproducibility and criterion validity by comparing the different subscales or groups of different items with other previously validated questionnaires.

The original questionnaire's sensitivity to change was studied in patients undergoing lumbar spine decompression surgery.

Stucki et $\mathrm{al}^{14}$ showed that this new instrument was valid, sensitive and reliable 
for the study of outcomes and health status in patients with lumbar spinal stenosis, and that it could be useful as a starting point in clinical trials of treatment, including spinal decompression surgery. However, no publications or studies for its validation in or cultural adaptation to Spanish have been found to date in the indexed literature.

The aims of this article are: to adapt the Zurich Claudication Questionnaire or Swiss Spinal Stenosis Questionnaire to the Spanish population, following the recommendations of the principal published guidelines ${ }^{15}$; to conduct a validation study on the new questionnaire in Spanish, plus a definition of its psychometric characteristics, in a population sample with lumbar spinal stenosis, including both patients who had undergone surgery and those who had not and to study the relationship between the Spanish Zurich Claudication Questionnaire, the Visual Analogic Scale (VAS) for pain and the principal questionnaires that assess disability due to low back pain (Oswestry Disability Index and Roland Morris Questionnaire) and health-related quality of life (EuroQoL 5D-3L: descriptive system and health status as perceived by patient), in the same population.

\section{METHODS}

The study was carried out in two phases. The first consisted of the translation and cross-cultural adaptation into Spanish, and the second was the validation study to show the psychometric characteristics of the questionnaire in Spanish.

\section{Cultural adaptation}

Our validation of the Spanish version of the Zurich Claudication Questionnaire (ZCQ), or Swiss Spinal Stenosis Questionnaire (SSSQ), followed the Principles of Good Practice for the Translation and Cultural Adaptation Process for Patient-Reported Outcome (PRO) Measures, recommended by the International Society for Pharmacoeconomics and Outcome Research (ISPOR) Task Force for translation and cultural adaptation ${ }^{15}$, as they provide a rational reason for following each of the steps proposed in their recommendations, define the phases and "characters" involved and warn of the risks of not following their recommendations.

We began by asking the questionnaire's author for authorisation for the cross-cultural adaptation and this was obtained by e-mail.

The project manager and director studied and defined the three ZCQ subscales, Symptom Severity (SSS), Physical Function (PFS) and Satisfaction (PSATS), and the questions that represent the pain (PD) and neuro-ischaemic symptom (NID) domains in the SSS subscale, as well as each of the items, its value and representativeness in the Spanish population.

Two independent translations were made into Spanish by native Spanish speakers. They were both checked by the authors, for errors and incorrect interpretations of ambiguous items. For example, one of the two versions literally translated distance travelled, in item 8 , giving values in miles or blocks, which cannot be interpreted by the Spanish population as it uses the International Metric System (IMS). The other version provided a translation with distance measured in more appropriate units for Spain, i.e. metres or blocks.

Also, in the PSATS questions, the English word "somewhat" had two possible translations in Spanish, either "algo" or "bastante", which have different meanings in the context of patient satisfaction.

The two Spanish translations were finally converted into a single text, with the aim of resolving the discrepancies between the two options through dialogue between the translators, the project manager and the person ultimately responsible, in order to avoid a translation biased by the personal style of a single translator. This solved the problems of the metric units, accepting the version used by the IMS, and the words "algo" and "bastante" were removed from the satisfaction questions to avoid creating confusion in the Spanish population.

This Spanish version was translated back into the source language (English) 
by two independent native English translators for the purpose of quality control. These versions were reviewed and showed that the quality of the translation was similar to and had the same meaning as the original.

A cognitive debriefing was conducted with 16 patients with lumbar spinal conditions either admitted to Hospital Complex of Navarre or from Spinal Surgery Unit outpatients to assess the comprehension and cognitive equivalence of the translation, check any alternative translations that had not been resolved by the translators, em- phasise any items that were not conceptually appropriate and identify other confounding problems. They were all native Spanish speakers who knew how to read and write. After the cognitive debriefing review, the translation was subject to a final reading, the definitive document was drafted and the reliability, validity and sensitivity study was conducted, respecting the same subscales and domains as are found in the original (Fig. 1). Attached at the end of the document are the Spanish version (Annex 1) and original version (Annex 2) of the Zurich Claudication Questionnaire.

\begin{tabular}{ll}
\hline Questions 1-3 & Pain Domain / Symptom Severity Subscale (SSS) \\
\hline Questions 4-7 & Neuro-ischaemic domain / Symptom Severity subscale (SSS) \\
\hline Questions 8-12 & Physical Function subscale (PFS) \\
\hline Questions 13-18 & Satisfaction subscale (PSATS) \\
\hline
\end{tabular}

Figure 1. Structure of the Zurich Claudication Questionnaire

\section{Validation study}

The study comprised 76 patients, of the Spinal Disease Unit of the Orthopaedic and Trauma Department of Hospital Complex of Navarre, 33 of whom had been admitted pending interlaminar epidural injection (INJ) and 43 of whom were outpatients.

The patients were selected consecutively during June 2013, from the consultation, if they were outpatients, and from the hospitalization if they were going under the epidural injection. The patients were identified by group: INJ vs. outpatient.

The inclusion criteria, in both groups, were to present symptoms of neurogenic claudication, defined as "unilateral or bilateral sensation of discomfort, pain or weakness in the shin, buttocks or thigh when the patient walks or remains standing for a long time, as a symptom of stenosis or narrowing of the spinal canal or inflammation of the nerves exiting the spinal cord" ${ }^{16}$. The patients also had to be adults and freely agree to participate in the study after being asked and informed of the process.
The exclusion criteria were tumour, infection, active-progressive arthritis of the knee or hip, peripheral circulatory disease, known peripheral neuropathy, ischaemic heart disease, chronic obstructive pulmonary disease and patients who did not write, speak or read fluent Castilian Spanish.

All the patients completed the questionnaire, provided in paper format, by themselves without the presence of an interviewer, thus avoiding the possible intimidating effect of the presence of healthcare personnel. All the patients responded on the first day (day 0) to the culturally-adapted Spanish versions of the Zurich Claudication Questionnaire (ZCQ), Oswestry Disability Index (ODI) ${ }^{17}$, Roland-Morris Questionnaire (RM) ${ }^{18}$ and EuroQol 5D-3L (EQ-5D) ${ }^{19}$.

The INJ patients also completed a Visual Analogue Scale (VAS) for pain, from 0 to 10 , being 0 the absence of pain, and 10 meaning the greatest level of experience pain.

The PSAT subscale of the ZCQ was only completed by patients who had previously 


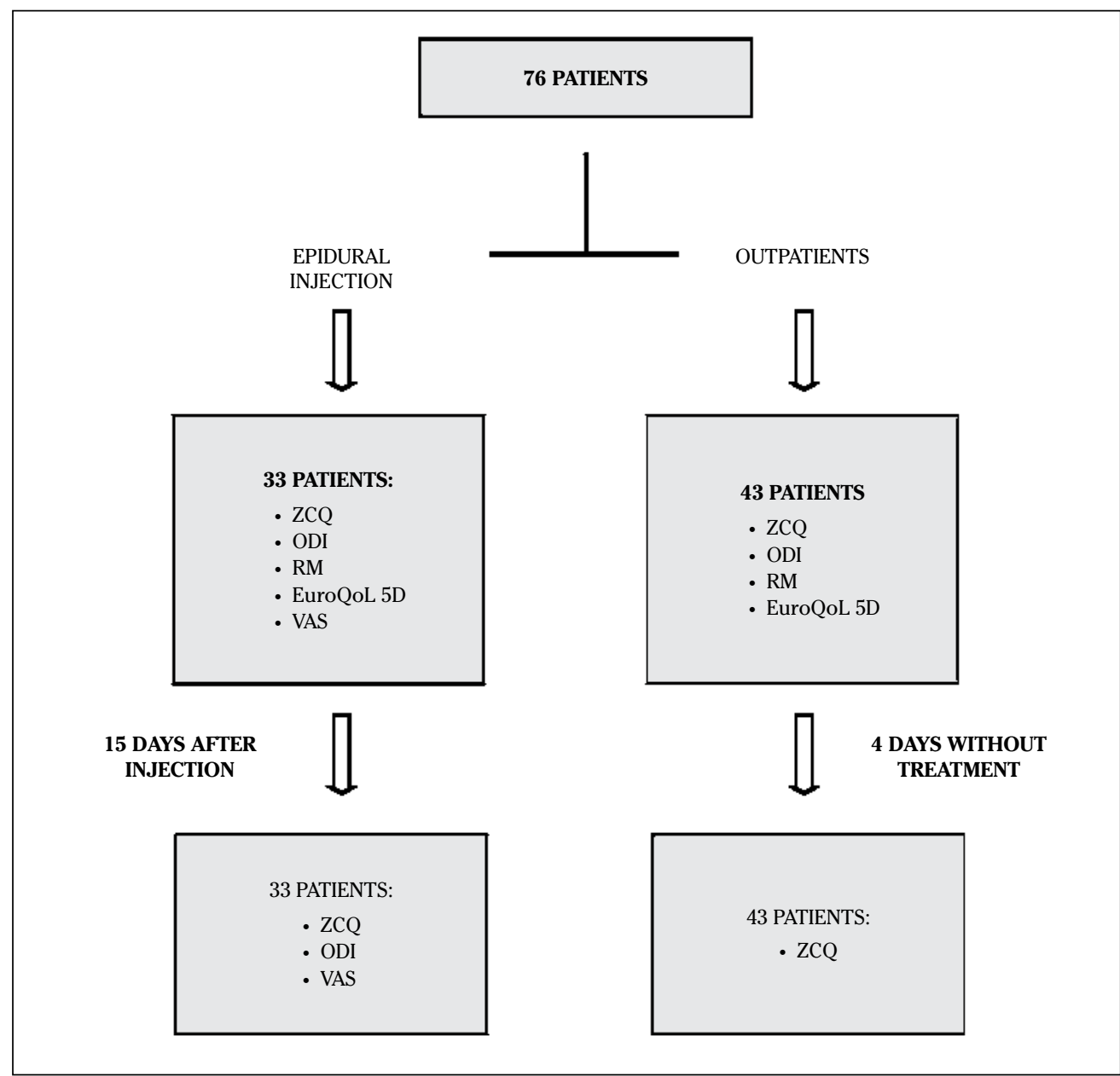

Figure 2. Study design.

undergone surgery (37 patients, 32 outpatients and 5 INJ).

The outpatients were re-surveyed with the ZCQ by telephone after 4-5 days (day 5) in order to test its reproducibility and the INJ patients were re-surveyed 2 weeks later (day 15) with ZCQ, ODI and VAS, to show whether there was sensitivity to change (Fig. 2).

The data were analysed with the SPSS 20.0 statistical software package. The qualitative variables are described with the distribution of frequencies of each of the categories and variables result of the ques- tionnaires. Semiquantitative variables, are presented as mean and standard deviation in order to increase the precision on the description, although the hypotheses were used nonparametric tests.

For baseline comparison of mean values of the different questionnaires between INJ and outpatient group was used Mann-Whitney U test. Internal consistency was examined using Cronbach's alpha statistic and the test-retest reliability was studied by the ZCQs completed by the outpatients on "Day 0" and "Day 5", using the Intraclass Coefficient of Correlation (ICC) ${ }^{20}$. Sensitiv- 
ity to change was studied using Wilcoxon test with the mean values of each item of the spanish ZCQ on day 0 and day $15^{21}$.

Criterion validity of the Spanish version of ZCQ was calculated by studying the correlation between each subscale or domain test with ODI, RM and EuroQoL 5D using the correlation coefficient rho of Spearman. We expected to find a good correlation between the results of ZCQ, and the other questionnaires.

Information was also gathered about the administration, the burden on the patient and the administrative burden.

\section{RESULTS}

The test was not difficult if the patient was able to read and had received a brief explanation. The time required to complete the questionnaire was around 5 minutes. The administrative burden was less than 5 minutes per ZCQ test when entering the answers to each item on a spreadsheet that automatically evaluated the scores.

Where several responses were ticked for the same item, the one with the highest score was considered. The final score was expressed as the arithmetic mean of the scores for each subscale and/or domain. The higher the score on each subscale, the worse the patient's perception of his or her health status or outcomes of possible treatments.

The mean age was 55.45 years (27-80) with a standard deviation (SD) of 13.56 . Forty four patients were male (57.9\%) and 32 women (42.1\%). During data collection, 2 patients were lost.

There were no significant differences between our two populations in the test on day 0 , except in the initial VAS score, which was higher in the INJ population (INJ VAS $=7.48$ vs. Outpatient VAS $=6.40, \mathrm{p}=0.033$ ) (Table 1).

The version of the ZCQ adapted to Spanish showed excellent reliability in all the subscales and domains on day 0 , with Cronbach alpha internal consistency values ranging from 0.796 for the NID of the SSS to 0.917 for the questionnaire overall (Table 2).
Test-retest reproducibility shows a very high correlation, almost close to 1 , that it is seen on all subscales of our construct, with the highest correlation on the subscale severity of symptoms (SSS - RE_SSS = 0.98), and its two domains of pain (DD_RE DD = 0.971 ), and neuro - ischemic (DNI_RE DNI = 0.969) (Table 2).

In the criterion validity study, by comparing the ZCQ with the RM, ODI, Pain-VAS and EuroQol 5D tests, the following Spearman's rho correlation coefficients were found (Table 3). The sensitivity to change in questionnaire scores 15 days after a therapeutic procedure such as epidural steroid injection are shown in table 4 .

All the differences between day 0 and day 15 , using the Wilcoxon text were significant, except for the SAT subscale. The greatest difference was found in the change in the PD domain (Difference PD day 0 vs. $\mathrm{PD}$ day $15=0.79 ; 95 \% \mathrm{CI}=0.41-1.117$, $\mathrm{p}<0.001$ ).

\section{DISCUSSION}

It is evident that the valid process to allow use of questionnaires or health measures from other languages is cross-cultural adaptation and not simple translation ${ }^{22}$.

The ISPOR Task Force for Translation and Cultural Adaptation established its Principles of Good Practice ${ }^{15}$ (used in the adaptation of our questionnaire) after analysing other previously described methods, producing a protocol of action which leads us step by step through the process, explaining who should be the key actors in each step, and describing the risks of not including that step.

One of the main criticisms, however, of these "Principles of Good Practice" is that they provide standards of conduct without strong scientific evidence. In this respect, McKenna harshly criticises the work of ISPOR ${ }^{22}$, and says that the work by Wild et $\mathrm{al}^{15}$, although worthy of praise, is merely a summary of the opinions of a number of organisations, which does not include scientific evidence and does not include an examination of the quality of the translation. Indeed, he criticises the 
Table 1. Comparison of baseline test scores of the "outpatient-INJ" populations.

\begin{tabular}{|c|c|c|c|c|c|}
\hline & Group & $\mathbf{N}$ & Mean & SD & $\mathbf{p}$ \\
\hline \multirow{2}{*}{ ODI } & INJ & 30 & 39,71 & 14,82 & \multirow{2}{*}{0.268} \\
\hline & Outpatient & 42 & 44,41 & 19,72 & \\
\hline \multirow{2}{*}{$\mathbf{R M}$} & INJ & 32 & 10,91 & 6,27 & \multirow{2}{*}{0.952} \\
\hline & Outpatient & 42 & 10,86 & 5,81 & \\
\hline \multirow{2}{*}{ EVA } & INJ & 29 & 7,38 & 1,01 & \multirow{2}{*}{0.033} \\
\hline & Outpatient & 10 & 6,40 & 1,43 & \\
\hline $\mathrm{ZCQ}$ & Group & $\mathbf{N}$ & Mean & SD & p \\
\hline \multirow{2}{*}{ SSS } & INJ & 33 & 3,30 & 0,60 & \multirow{2}{*}{0.941} \\
\hline & Outpatient & 43 & 3,25 & 0,84 & \\
\hline \multirow{2}{*}{ PD } & INJ & 33 & 3,83 & 0,53 & \multirow{2}{*}{0.966} \\
\hline & Outpatient & 43 & 3,66 & 0,96 & \\
\hline \multirow{2}{*}{ NID } & INJ & 33 & 2,91 & 0,81 & \multirow{2}{*}{0.908} \\
\hline & Outpatient & 43 & 2,94 & 1,04 & \\
\hline \multirow{2}{*}{ PFS } & INJ & 33 & 2,34 & 0,59 & \multirow{2}{*}{0.464} \\
\hline & Outpatient & 43 & 2,43 & 0,73 & \\
\hline \multirow{2}{*}{ PSATS } & INJ & 5 & 2,23 & 0,52 & \multirow{2}{*}{0.823} \\
\hline & Outpatient & 32 & 2,16 & 0,63 & \\
\hline
\end{tabular}

ODI: Oswestry Disability Index. RM: Roland Morris Questionare. EVA: Escale visual onclogical. ZCQ: Zurich Claudication Questionare. SSS: Measures Symtoms severity. PD: Pain domain. NID: Neuro-ischaemic symptoms. PFS: Measures physical function. PSATS: Patient's satisfaction

Table 2. Reliability of Spanish version of ZCQ: internal consistency and reproducibility

\begin{tabular}{lcc}
\hline $\begin{array}{c}\text { Spanish } \\
\text { ZCQ Reliability }\end{array}$ & $\begin{array}{c}\text { Internal Consistency: } \\
\text { Cronbach alfa }\end{array}$ & $\begin{array}{c}\text { Reproducibility: } \\
\text { Intraclass Coefficient of Correlation }\end{array}$ \\
\hline Q1-Q18 (total ZCQ) & 0.917 & $0.980(\mathrm{p}<0.01)$ \\
\hline Q1-Q7 (SSS) & 0.810 & $0.971(\mathrm{p}<0.01)$ \\
\hline Q1-Q3 (PD) & 0.865 & $0.969(\mathrm{p}<0.01)$ \\
\hline Q4-Q7 (NID) & 0.796 & $0.965(\mathrm{p}<0.01)$ \\
\hline Q8-Q12 (PFS) & 0.857 & $0.933(\mathrm{p}<0.01)$ \\
\hline Q13-Q18 (PSATS) & 0.880 & \\
\hline
\end{tabular}

Table 3. Correlation of ZCQ with low back pain and quality of life assessment questionnaires (n.s. = not significant)

\begin{tabular}{ccccc}
\hline Spearman's rho & Oswestry & Roland Morris & Pain VAS & EuroQoL VAS \\
\hline SSS & 0.552 & 0.239 & 0.397 & -0.472 \\
\hline PD & 0.503 & 0.1 (n.s.) & 0.441 & -0.521 \\
\hline NID & 0.424 & 0.279 & 0.289 (n.s.) & -0.364 \\
\hline PFS & 0.660 & 0.224 (n.s.) & 0.464 & -0.519 \\
\hline PSAT & 0.426 & 0.472 & 0.602 (n.s.) & -0.411 \\
\hline
\end{tabular}

Table 4. Sensitivity to change. Wilcoxon test ZCQ Day 0 - Day 15

\begin{tabular}{cccc}
\hline Mean difference Day 0-15 & Difference & 95\% CI Difference & P \\
\hline SSS & 0.55 & $0.28-0.83$ & 0.001 \\
\hline PD & 0.79 & $0.41-1.17$ & $<0.001$ \\
\hline NID & 0.38 & $0.13-0.63$ & 0.004 \\
\hline PFS & 0.36 & $0.17-0.55$ & 0.001 \\
\hline PSATS & -0.40 & $-1.58-0.77$ & 0.465 \\
\hline
\end{tabular}


concept of back translation since, if the forward translation is well done, the back translation could well be nothing like the original questionnaire.

This conflict was found in our translation, as English units of distance (miles) had to be converted to the international metric system (kilometres).

Also, for the Spanish population in our sample, a time concept had to be added to walked distance, so question 8 of the Spanish adaptation of the ZCQ not only refers to units of distance according to the international metric system, but includes a time unit in some responses (3 kilometres vs. 1 hour), which is not found in the original. In our case, the back translation could have provided little useful but much confounding information.

The solution is to produce a quality translation and subsequently check it, because it would be poor practice to simply assume that a translated version has the same psychometric properties as the original. In fact, the data obtained in our statistical study shows that the Spanish version of the ZCQ has the same psychometric reliability, validity and sensitivity characteristics as the original test.

With regards to reliability ${ }^{14}$ the internal consistency of our test appears to be slightly greater than that of the original in the symptom severity subscale and its domains.

Our study analyses the questionnaire's reproducibility by Intraclass Coefficients of Correlation, with very good results. These data are consistent with those of the original version, which studies test-retest by Spearman's Correlation Coefficient.

A few years ago, Pratt et $\mathrm{al}^{10}$ published good reproducibility and internal consistency data, but without distinguishing between the questionnaire's subscales, so our results cannot be compared to theirs.

The adaptation of the ZCQ to Spanish maintained the validity of content of the original, thanks to the translation and cultural adaptation process, and has been shown to have criterion validity in the study of association with the principal low back pain dysfunction (ODI, RM, VAS) and health-related quality of life (EuroQoL 5D) questionnaires.

As expected, the greatest correlation of the ZCQ with the ODI was in the physical function (PF) subscale, which makes sense and adds validity to our test, as the ODI is a questionnaire that primarily evaluates the interviewee's disability, as does this ZCQ subscale.

The lack of correlation between the RM questionnaire and the PF subscale of the ZCQ, although it might seem contradictory for the purposes of our study, is due to the fact that the RM specifically measures disability induced by back pain, and the ZCQ measures health related to the claudication caused by lumbar spinal stenosis.

The data of the analysis of correlation between the ZCQ and EuroQoL strengthens the criterion validity of our test, because the patients who felt sicker, according to the perceived health status scale (EuroQoL VAS), were those who presented more pain and physical limitation in the ZCQ.

Although in the original study the correlation between the Pain-VAS and the SSS is more intense than in ours, this could be because, in the original, the population comprised patients who were pending surgery, so their condition would have been more severe than that of our patients.

Among the other classic psychometric characteristics, it is shown that this version of the test is sensitive to the change induced by epidural injection in a 15-day period. In the original $\mathrm{ZCQ}^{14}$, the change detected in the PFS was greater than in our test. However, the change in the PD domain of the SSS was greater in our sample. This difference could be due to the therapeutic intervention applied, as 15 days after INJ, there seems to be greater improvement in pain than in physical function, yet the opposite is true 6 months after lumbar spine decompression surgery.

One possible limitation of our study is that the Zurich Claudication Questionnaire was developed specifically for patients with lumbar spinal stenosis (LSS) who have undergone surgery. However, having undergone spinal surgery was not an essential requirement for our study, as we 
wanted to study the change with conservative measures such as epidural blockage, and generate records for future studies of their efficacy.

In 2012, Cleland et $\mathrm{al}^{11}$ published the psychometric properties of the ODI, ZCQ, Patient Specific Functional Scales and Numeric Pain Rating Scale in LSS patients who had not undergone surgery, after receiving 2 different physiotherapy programmes ${ }^{23}$. In their "test-retest" reproducibility study, only the ODI showed an Intraclass Coefficient of Correlation classified as excellent (ICC $=0.836$ ), while the Symptom Severity and Physical Function subscales of the ZCQ showed a moderate ICC $(0.673$ and 0.724 , respectively), finding lower reproducibility in their population than in the original study (Symptom Severity rho $=0.73$, Physical Function rho $=0.68$ ).

They attribute these differences to the time between questionnaire administrations ( 6 weeks for Cleland et al, 6 months for Stucki et al), as it has been suggested that the tests could be less reliable and sensitive over time ${ }^{24}$. The better results obtained in our sample in this respect might have been different if we had left a longer interval between the test and retest, although LSS is a chronic condition and should not initially present clinical change.

However, personal perception of the way the condition evolves can fluctuate and we believe that 5 days can be sufficient for avoiding memory bias in the responses, while maintaining subjective perception of the disease.

For the study of sensitivity to change, we performed a therapeutic intervention in the form of epidural steroid injection, which is not $100 \%$ effective in all patients and in some cases is only effective in the short term ${ }^{25,26}$.

As the initial purpose was to describe the test's psychometric characteristics and not to study the efficacy of epidural blockage, we considered that 2 weeks was enough to ensure sufficient significant difference in our population.

In conclusion, this study has provided a version of the Zurich Claudication Questionnaire or Swiss Spinal Stenosis
Questionnaire translated and cross-culturally adapted to Spanish, with psychometric characteristics that show its high reliability, validity and sensitivity.

These tested properties provide the Spanish population with the Zurich Claudication Questionnaire for evaluation of the outcomes and health status as perceived by patients with lumbar spinal stenosis and claudication syndrome.

The Spanish version of the ZCQ showed the expected relationships to the principal back pain assessment and health-related quality of life questionnaires.

\section{REFERENCES}

1. Brage S, Nygard JF, Tellnes G. The gender gap in musculoskeletal-related long-term sickness absence in Norway. Scand J Soc Med 1998; 26: 34-43.

2. Lim KL, Jacobs P, KlaRenbach S. A population-based analysis of healthcare utilization of persons with back disorders: results from the Canadian Community Health Survey 2000-2001. Spine (Phila Pa 1976) 2006; 31: 212-218.

3. Maetzel A, Li L. The economic burden of low back pain: a review of studies published between 1996 and 2001. Best Pract Res Clin Rheumatol 2002; 16: 23-30.

4. ThiEHoff R. [Economic significance of work disability caused by musculoskeletal disorders]. Orthopade 2002; 31:949-956.

5. Boss N AM. Spinal disorders. Fundamentals of Diagnosis and Treatment. Berlin Heidelberg New York: Springer-Verlag. 2008.

6. Sigmundsson FG, Jonsson B, Stromevist B. Impact of pain on function and health related quality of life in lumbar spinal stenosis. A register study of 14,821 patients. Spine (Phila Pa 1976) 2013; 38: E937-945.

7. Fairbank JC, Pynsent PB. The Oswestry Disability index. Spine (Phila Pa 1976) 2000; 25: 2940-2952.

8. Roland M, Fairbank J. The Roland-Morris Disability Questionnaire and the Oswestry Disability Questionnaire. Spine (Phila Pa 1976) 2000; 25: 3115-3124.

9. Roland M, Morris R. A study of the natural history of back pain. Part I: development of a reliable and sensitive measure of disability in low-back pain. Spine (Phila Pa 1976) 1983; 8: 141-144. 
10. Pratt RK, Fairbank JC, VIRR A. The reliability of the Shuttle Walking Test, the Swiss Spinal Stenosis Questionnaire, the Oxford Spinal Stenosis Score, and the Oswestry Disability Index in the assessment of patients with lumbar spinal stenosis. Spine (Phila Pa 1976) 2002; 27: 84-91.

11. Cleland JA, Whitman JM, Houser JL, Wainner RS, CHILDs JD. Psychometric properties of selected tests in patients with lumbar spinal stenosis. Spine J 2012; 12: 921-931.

12. Mannion AF, Elfering A. Predictors of surgical outcome and their assessment. Eur Spine J 2006; 15 Suppl 1: S93-108.

13. Elfering A, Semmer NK, Schade V, Grund S, Boos N. Supportive colleague, unsupportive supervisor: the role of provider-specific constellations of social support at work in the development of low back pain. J Occup Health Psychol 2002; 7: 130-140.

14. Stucki G, Daltroy L, Liang MH, Lipson SJ, FosSEL AH, KATZ JN. Measurement properties of a self-administered outcome measure in lumbar spinal stenosis. Spine (Phila Pa 1976) 1996; 21: 796-803.

15. Wild D, Grove A, Martin M, Eremenco S, McElroy S, VerJee-Lorenz A et al. Principles of Good Practice for the Translation and Cultural Adaptation Process for Patient-Reported Outcomes (PRO) Measures: report of the ISPOR Task Force for Translation and Cultural Adaptation. Value Health 2005; 8: 94-104.

16. Conway J, Tomkins CC, HaIG AJ. Walking assessment in people with lumbar spinal stenosis: capacity, performance, and self-report measures. Spine J 2011; 11: 816-823.

17. Flórez García Mt, Armenteros Pedreros J, Álvarez Prado A, Martínez Lorente MD. Adaptación transcultural a la población española de la escala de incapacidad por dolor lumbar de Oswestry. Rehabilitación (Madr) 1995; 29: 138-145.
18. Kovacs FM, Llobera J, Gil Del Real MT, AbralRa V, Gestoso M, Fernandez C et al. Validation of the spanish version of the Roland-Morris questionnaire. Spine (Phila Pa 1976) 2002; 27: 538-542.

19. Badia X, Roset M, Montserrat S, Herdman M, SeGURA A. La versión española del EuroQol: descripción y aplicaciones. Escala de calidad de vida europea. Med Clin (Barc) 1999; 112 Suppl 1: 79-85.

20. Deyo RA, Diehr P, Patrick DL. Reproducibility and responsiveness of health status measures. Statistics and strategies for evaluation. Control Clin Trials 1991; 12 (4 Suppl): 142S-158S.

21. Husted JA, Cook RJ, Farewell VT, Gladman DD. Methods for assessing responsiveness: a critical review and recommendations. J Clin Epidemiol 2000; 53: 459-468.

22. McKenna SP, Doward LC. The translation and cultural adaptation of patient-reported outcome measures. Value Health 2005; 8: 89-91.

23. Whitman JM, Flynn TW, Childs JD, Wainner RS, GILl HE, Ryder MG, et al. A comparison between two physical therapy treatment programs for patients with lumbar spinal stenosis: a randomized clinical trial. Spine (Phila Pa 1976) 2006; 31:2541-2549.

24. Beurskens AJ, de Vet HC, Koke AJ. Responsiveness of functional status in low back pain: a comparison of different instruments. Pain 1996; 65: 71-76.

25. Ridley MG, Kingsley GH, Gibson T, Grahame R. Outpatient lumbar epidural corticosteroid injection in the management of sciatica. $\mathrm{Br} \mathrm{J}$ Rheumatol 1988; 27: 295-299.

26. Buchner M, Zeifang F, Brocai DR, Schiltenwolf M. Epidural corticosteroid injection in the conservative management of sciatica. Clin Orthop Relat Res 2000 ; 375: 149-156. 


\section{Anexo 1 \\ Cuestionario de claudicación de Zurich}

\section{Durante el último mes, ¿cómo describiría...}

1) ... el dolor que ha experimentado, de media, teniendo en cuenta su dolor de espalda, glúteos y piernas? 1. Ausente

2. Leve

3. Moderado

4. Intenso

5. Muy intenso

2) ... cuán a menudo ha experimentado dolor en la espalda, los glúteos o las piernas?

1. Menos de una vez por semana

2. Como mínimo una vez por semana

3. Cada día, durante como mínimo unos minutos

4. Cada día, durante la mayor parte del día

5. Cada día, a todas horas

3) ... el dolor que ha sentido en la espalda o los glúteos?

1. Ausente

2. Leve

3. Moderado

4. Intenso

5. Muy intenso

4) ... el dolor que ha sentido en las piernas o los pies?

1. Ausente

2. Leve

3. Moderado

4. Intenso

5. Muy intenso

5) ... el entumecimiento u hormigueo que ha sentido en las piernas o pies?

1. Ausente

2. Leve

3. Moderado

4. Intenso

5. Muy intenso

6) ... la debilidad que ha sentido en las piernas o pies?

1. Ausente

2. Leve

3. Moderada

4. Intensa

5. Muy intensa

7) ... sus problemas de equilibrio?

1. No, no he tenido problemas de equilibrio.

2. Sí, a veces me falta el equilibrio o no me siento con paso firme.

3. Sí, a menudo me falta el equilibrio o no me siento con paso firme.

Durante el último mes, en un día normal...

8) ... ¿cuánto ha sido capaz de caminar?

1. Más de $3 \mathrm{~km}$ o una hora

2. Más de un par de manzanas, pero menos de $3 \mathrm{~km}$ o menos de una hora

3. Más de 15 metros, pero menos de un par de manzanas

4. Menos de 15 metros
9) ... ¿ha salido a pasear o ha ido a centros comerciales por placer?

1. Sí, sin problemas

2. Sí, aunque a veces con dolor

3. Sí, pero siempre con dolor

4. No

10) ... ¿ha ido a hacer la compra o de tiendas?

1. Sí, sin problemas

2. Sí, aunque a veces con dolor

3. Sí, pero siempre con dolor

4. No

11) ... ¿ha caminado por las diferentes habitaciones de su casa o apartamento?

1. Sí, sin problemas

2. Sí, aunque a veces con dolor

3. Sí, pero siempre con dolor

4. No

12) ... ¿ha caminado desde su dormitorio hasta el baño?

1. Sí, sin problemas

2. Sí, aunque a veces con dolor

3. Sí, pero siempre con dolor

4. No

¿Cómo está de satisfecho con..

13) ... el resultado global de su operación de espalda?

1. Muy satisfecho/a

2. Satisfecho/a

3. Insatisfecho/a

4. Muy insatisfecho/a

14) ... el alivio del dolor después de la operación?

1. Muy satisfecho/a

2. Satisfecho/a

3. Insatisfecho/a

4. Muy insatisfecho/a

15) ... su capacidad de caminar después de la operación?

1. Muy satisfecho/a

2. Satisfecho/a

3. Insatisfecho/a

4. Muy insatisfecho/a

16) ... su capacidad de realizar su trabajo habitual, tareas domésticas o trabajos de jardinería?

1. Muy satisfecho/a

2. Satisfecho/a

3. Insatisfecho/a

4. Muy insatisfecho/a

17) ... la fuerza de sus muslos, piernas y pies?

1. Muy satisfecho/a

2. Satisfecho/a

3. Insatisfecho/a

4. Muy insatisfecho/a

18) ... su equilibrio o la firmeza de su paso?

1. Muy satisfecho/a

2. Satisfecho/a

3. Insatisfecho/a

4. Muy insatisfecho/a 


\section{Annex 2 \\ Zurich claudication questionnaire}

\section{In the last month, how would you describe:}

1) The pain you have had on average including pain in your back, buttocks and pain that goes down the legs?
1. None
2. Mild
3. Moderate
4. Severe
5. Very Severe

2) How often have you had back, buttock, or leg pain? 1. Less than once a week

2. At least once a week

3. Everyday, for at least a few minutes

4. Everyday, for most of the day

5 . Every minute of the day

3) The pain in your back or buttocks?

1. None

2. Mild

3. Moderate

4. Severe

5. Very Severe

4) The pain in your legs or feet?

1. None

2. Mild

3. Moderate

4. Severe

5. Very Severe

5) Numbness or tingling in your legs or feet?
1. None
2. Mild
3. Moderate
4. Severe
5. Very Severe

6) Weakness in your legs or feet?

1. None

2. Mild

3. Moderate

4. Severe

5. Very Severe

7) Problems with your balance?

1. No, I've had no problems with balance

2. Yes, sometimes I feel my balance is off, or that I am not sure-footed

3. Yes, often I feel my balance is off, or that I am not sure-footed.

\section{In the Last Month, on a Typical Day:}

8) How far have you been able to walk?

1. Over 2 miles

2. Over 2 blocks, but less than 2 miles

3. Over 50 feet, but less than 2 blocks

4. Less than 50 feet
9) Have you taken walks outdoors or in malls for pleasure?

1. Yes, comfortably

2. Yes, but sometimes with pain

3. Yes, but always with pain

4. No

10) Have you been shopping for groceries or other items?

1. Yes, comfortably

2. Yes, but sometimes with pain

3. Yes, but always with pain

4. No

11) Have you walked around the different rooms in your house or apartment?

1. Yes, comfortably

2. Yes, but sometimes with pain

3 . Yes, but always with pain

4. No

12) Have you walked from your bedroom to the bathroom? 1. Yes, comfortably

2. Yes, but sometimes with pain

3 . Yes, but always with pain

4. No

\section{How Satisfied Are You With:}

13) The overall result of back operation?

1. Very satisfied

2. Somewhat satisfied

3. Somewhat dissatisfied

4. Very dissatisfied

14) Relief of pain following the operation?

1. Very satisfied

2. Somewhat satisfied

3. Somewhat dissatisfied

4. Very dissatisfied

15) Your ability to walk following the operation

1. Very satisfied

2. Somewhat satisfied

3. Somewhat dissatisfied

4. Very dissatisfied

16) Your ability to do housework, yard work, or job following the operation?

1. Very satisfied

2. Somewhat satisfied

3. Somewhat dissatisfied

4. Very dissatisfied

17) Your strength in the thighs, legs, and feet?

1. Very satisfied

2. Somewhat satisfied

3. Somewhat dissatisfied

4. Very dissatisfied

18) Your balance, or steadiness on your feet?

1. Very satisfied

2. Somewhat satisfied

3. Somewhat dissatisfied

4. Very dissatisfied 